China Perspectives

46 | march-april 2003

Varia

\title{
The Birth of a Chinese Language Opera
}

Snow in August by Gao Xingjian

\section{Noël Dutrait}

\section{OpenEdition}

\section{Journals}

Édition électronique

URL : http://journals.openedition.org/chinaperspectives/263

DOI : 10.4000/chinaperspectives.263

ISSN : 1996-4617

Éditeur

Centre d'étude français sur la Chine contemporaine

Édition imprimée

Date de publication : 15 avril 2003

ISSN : 2070-3449

Référence électronique

Noël Dutrait, « The Birth of a Chinese Lanquage Opera », China Perspectives [En ligne], 46 | march-april 2003, mis en ligne le 29 août 2006, consulté le 28 octobre 2019. URL : http://journals.openedition.org/ chinaperspectives/263 ; DOI : 10.4000/chinaperspectives.263

Ce document a été généré automatiquement le 28 octobre 2019

(c) All rights reserved 


\title{
The Birth of a Chinese Language Opera
}

\author{
Snow in August by Gao Xingjian
}

Noël Dutrait

\section{NOTE DE L'ÉDITEUR}

Translated from the French original by Michael Black

1 The première of the opera Snow in August ${ }^{1}$, written and directed by Gao Xingjian, took place in Taipei on December 19th 2002. Announced months ago in the Taiwanese press, this creation is exceptional for several reasons. A Taiwanese production, it features actors from the Peking Opera of Taiwan, including the famous $\mathrm{Wu}$ Hsing-kuo in the main role, an orchestra, Taiwanese choirs and singers, a French conductor and lighting designer, Marc Trautmann and Philippe Grosperrin, as well as a composer from mainland China, who lives in France, $\mathrm{Xu}$ Shuya $^{2}$. While the casting itself may be surprising, so is the cost of the production: fifteen million Taiwanese dollars (just under 400,000 euros), according to the producer Tchen Yu-chiou, who is also President of the Cultural Affairs Committee of Taiwan, in other words Minister of Culture, and whose energy has allowed her to overcome all the obstacles the project has encountered ${ }^{3}$.

2 This enormous mustering of resources has not been devoted to a show which is likely to draw the crowds, such as a musical comedy or a rock concert. Rather it is the production and the setting to music of a work whose meaning is far from immediately obvious : the story of the Sixth Patriarch Huineng, a Chan (Zen) Buddhist master very familiar to the Taiwanese public, but known only to those Westerners who are passionately interested in Zen Buddhism ${ }^{4}$.

3 As at each stage of his polymorphous creative career, Gao Xingjian surprises, worries, disturbs, and provokes argument and extreme reactions. Just as A Preliminary Discussion of the Art of Modern Fiction was a landmark in the revival of Chinese literature in 1981, as the production of Bus Stop in 1983 introduced the renewal of spoken theatre in China, as 
Soul Mountain, in 1991, had blazed a trail for a new form of novelistic expression in Chinese language literature-an innovation clearly underlined in the reasons behind the choice of the Nobel Academy in 2000-, the creation of Snow in August will be recognised as an important date in the history of contemporary opera and will certainly mark the birth of a modern Chinese language opera.

The idea which runs through all Gao Xinjian's/Xingjian's? work is also present in Snow in August: like the characters in his novels and plays, the main character, the Sixth Patriarch Huineng, is not a "saviour of humanity" after the fashion of Buddha, Jesus, Muhammad, Marx, Nietzsche or Mao Zedong. He invites each individual to save himself by rejecting all showy rags and external signs of distinction-in this case the monk's robes and bowl handed down from master to master from the beginning. To Huineng the only way to save oneself and to save the "doctrine" lies in flight, the praises of which Gao Xingjian has sung on many occasions, in his novels, in a play by the same name ${ }^{5}$, and in the speech made at Stockholm, on the day he received the Nobel Prize for literature: "Cold literature is a literature of flight in order to save one's own life, it is a literature of spiritual protection of oneself in order to avoid being stifled by society" 6 . In the same way, Huineng flees on the advice of his master Hongren who advises him: "Go, find refuge in the south and then act to change those who are lost, in order to help all beings to cross the ocean of existence".

In Snow in August, Gao Xingjian also portrays a writer who is indifferent to the turbulence of the world, who wants to hear a song, "Snow in August" sung by a beautiful woman-the singer-, who is herself the sensuous double of the nun Infinite Treasure, to whose house Huineng came to deliver some wood and who initiated him into Buddhism. The character of nun Infinite Treasure, who seeks to withdraw from the world (chushi), accompanied by her double, the singer, who, on the contrary "enters the world" (rushi), represents Gao Xingjian's constant questioning of his female characters, whether in Soul Mountain, One Man's Bible, or even in the more intimate plays. How to know, appreciate, and live with a woman without considering one's sensuality and the sexual desire which, inevitably, transforms relations between men and women?

6 The final scene of Snow in August, "Pandemonium in the Chan community" seems to represent the chaos witnessed by Gao Xingiian as writer, painter and human being, who suffers acutely from the misfortunes of the world and his own inability to change it.

7 The audience, whether Taiwanese or Western, not always familiar with the philosophical and metaphysical preoccupations of Gao Xingjian, is sometimes likely to find it difficult to understand his intentions, in the manner of the Taiwanese spectator who declared, the day after the first performance, that having seen this opera, he realised that he understood nothing of "Chan", which he had previously believed he knew well !

8 Gao Xingjian practises a form of total art which marries effectively with his approach: he asked a Chinese composer, who, like him, lives in France, to compose a superlative score, which avoids any of the forms of "Chineseness" one might have dreaded, at times lyrical, at others perfectly modern, while not hesitating to bring in the melancholy sound of the xun, a kind of clay ocarina, next to percussion instruments from Peking opera and the strident chords of Western string instruments. One Taiwanese critic saw

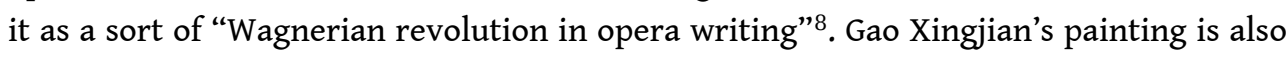
in evidence, as a number of scenes take place in front of enlargements of his ink washes, which range across tones from black to white, taking in the most subtle shades 
of grey, and which give off a poetic power well known to lovers of his art. Moreover in the production, which he directed himself, dancing and acrobatics appear all through the show, and are perfectly integrated into the work.

The sober sets, ingenious lighting and magnificent costumes, which are the work of Yip Kam-tim, who won an Oscar for the film Crouching Tiger Hidden Dragon, serve Snow in August with discretion and effect.

The Taiwanese press highlighted the preparation of this unusual show. Gao Xingjian travelled to Taipei three months before the opening in order to "train" outstanding actors from Peking opera, making them "forget" the techniques they had acquired during a training that began in childhood, in order to invent a new style of diction, declamation and song which is both the recital of Mozart's opera and the Wagnerian arioso. The press, and Gao Xingjian himself, stressed that Snow in August was both an opera and a play without being either one or the other. The libretto as performed in Taipei is noticeably different from the play ${ }^{9}$. It is much shorter and has different characters (for example, Western opera singers such as a soprano and a baritone). The response from the Taiwanese critics was generally positive, although a certain puzzlement was detectable.

11 Once again, borne along by a commanding interior artistic necessity, Gao Xingjian has brought to life one of his "wild dreams", disturbing and shaking up habits, in order to create an innovative work to mark the beginning of the new millenium. Snow in August is neither totally Eastern nor totally Western, spectators who believed they knew Chan Buddhism are full of questions, those who thought that Gao Xingjian was a modernist author-an Eastern Ionesco or Beckett-are wondering why he is coming back to Chan Buddhism. Going as far as to take on the Peking opera tradition, Gao Xingjian destabilises, disturbs and confuses the issue. Neither Chinese nor Western, neither modern nor traditional, he provides no keys to the interpretation of his work, but wants people to find these keys themselves. He delegates to no-one the direction of his creation and, as he has always done, sometimes at the risk of his own life, labours relentlessly in order to accomplish his work.

Performances of Snow in August are planned for Hong Kong and the West. In November 2003, the Marseille Opera, which has collaborated in this work from the beginning, with the conductor Marc Trautmann and the lighting designer Philippe Grosperrin, will present the opera in the context of "Gao Year", organised by the city council of Marseille.

\section{NOTES}

1. A richly illustrated book was published to mark the premiere of Snow in August : Zhou Meihui, Xuedi chansi (Snowscape and Chan Thought), Taipei, Lianjing chubanshe, 2002. 2. It is worth remarking that in the Western tradition, there is more talk of the composer of the music of an opera than of the autor of the libretto, when in the case of Snow in August, the situation was the opposite : it was Gao Xingjian who commisioned 
the music from the composer, who achieved the impossible by completing the score in few months.

3. See the report in the bilingual (English and Chinese) journal Sinorama, October 2002, pp. 80-87, and in French the same report published in the journal Taipei aujourd'hui, décembre 2002, pp. 32-39.

4. See Fa-hai, Le Soûtra de l'Estrade du Sixième Patriarche Houei-neng (638-713), traduit et commenté par Patrick Carré, Paris, Points Seuil, 1995 ; Discours et sermons de Houeï-nêng, sixième patriarche Zen, traduction de Lucien Houlné, Paris, Albin Michel, 1984.

5. Gao Xingjian, La Fuite, Carnières (Belgique), éditions Lansman, 1992.

6. Gao Xingjian, La Raison d'être de la littérature, traduit par Noël et Liliane Dutrait, éditions de l'Aube, 2000, p. 17.

7. See the article by Zhou Meihui, "Yanchu "yu dao houlai yu hao"' (The further performance goes, the better it is), Lianhebao, 20 décembre 2002, p. 14.

8. See Andrew Huang, "Gao Xingjian puts Wagnerian vision to the test", Taiwan News, December 20, 2002, p. 6.

9. Bayuexue, Taipei, Lianjing chubanshe, 2000. 